\title{
Effects of long-term soil and crop management on soil hydraulic properties for claypan soils
}

\author{
A. Mudgal, S.H. Anderson, C. Baffaut, N.R. Kitchen, and E.J. Sadler
}

\begin{abstract}
Various land management decisions are based on local soil properties. These soil properties include average values from soil characterization for each soil series. In reality, these properties might be variable due to substantially different management, even for similar soil series. This study was conducted to test the hypothesis that for claypan soils, hydraulic properties can be significantly affected by long-term soil and crop management. Sampling was conducted during the summer of 2008 from two fields with Mexico silt loam (Vertic Epiaqualfs). One field has been under continuous row crop cultivation for over 100 years (Field), while the other field is a native prairie that has never been tilled (Tucker Prairie). Soil cores $(76 \times 76 \mathrm{~mm}[3.0 \times 3.0 \mathrm{in}])$ from six replicate locations from each field were sampled to a $60 \mathrm{~cm}$ (24 in) depth at $10 \mathrm{~cm}$ (3.9 in) intervals. Samples were analyzed for bulk density, saturated hydraulic conductivity $\left(\mathrm{K}_{\mathrm{sat}}\right)$, soil water retention, and pore-size distributions. Values of coarse (60 to $1,000 \mu \mathrm{m}$ [0.0024 to $0.039 \mathrm{in}]$ effective diameter) and fine mesoporosity (10 to $60 \mu \mathrm{m}$ [0.00039 to $0.0024 \mathrm{in}]$ effective diameter) for the Field site $\left(0.044\right.$ and $0.053 \mathrm{~m}^{3} \mathrm{~m}^{-3}$ [0.044 and $\left.\left.0.053 \mathrm{in}^{3} \mathrm{in}^{-3}\right]\right)$ were almost half those values from the Tucker Prairie site $(0.081$ and $0.086 \mathrm{~m}^{3} \mathrm{~m}^{-3}\left[0.081\right.$ and $\left.\left.0.086 \mathrm{in}^{3} \mathrm{in}^{-3}\right]\right)$. The geometric mean value of $\mathrm{K}_{\text {sat }}$ was 57 times higher in the native prairie site $\left(316 \mathrm{~mm} \mathrm{~h}^{-1}\left[12.4 \mathrm{in} \mathrm{hr}^{-1}\right]\right)$ than in the cropped field $(5.55$ $\mathrm{mm} \mathrm{h}^{-1}$ [0.219 in $\left.\mathrm{hr}^{-1}\right]$ ) for the first $10 \mathrm{~cm}$ (3.9 in) interval. Differences in $\mathrm{K}_{\text {sat }}$ values were partly explained by the significant differences in pore-size distributions. The bulk density of the surface layer at the Tucker Prairie site $\left(0.81 \mathrm{~g} \mathrm{~cm}^{-3}\left[50.6 \mathrm{lb} \mathrm{ft}^{-3}\right]\right)$ was two-thirds of the value at the Field site $\left(1.44 \mathrm{~g} \mathrm{~cm}^{-3}\left[89.9 \mathrm{lb} \mathrm{ft}^{-3}\right]\right)$, and was significantly different throughout the soil profile, except for the 20 to $30 \mathrm{~cm}$ (7.9 to 12 in) depth. These results show that row crop management and its effect on soil loss have significantly altered the hydraulic properties for this soil. Results from this study increase our understanding of the effects of long-term soil management on soil hydraulic properties.
\end{abstract}

Key words: claypan — native prairie - pore-size distributions - row crop—saturated hydraulic conductivity- soil water retention.

\begin{abstract}
An essential aspect of the Conservation Effects Assessment Project (CEAP) is to investigate the impact of various conservation practices and their spatial positioning on water and soil quality within a watershed (Duriancik et al. 2008). Simulation modeling is extensively used to assess the impacts of conservation practices on water quality in watersheds. The accuracy of simulation modeling depends upon using reliable and precise input data. Hydrologic simulation models are highly sensitive to soil hydraulic properties, which strongly influence model output related to water quality
\end{abstract}

Lowery 2003). A major impact of erosion is often the removal of a coarse-textured topsoil and exposure of a fine-textured subsoil at the surface that often has higher bulk density and lower hydraulic conductivity (Seobi et al. 2005; Jagadamma et al. 2009). Perennial vegetation is an additional factor, which can reduce the amount of surface runoff and the rate of erosion (van Rompaey et al. 2001); this perennial vegetation may create differences in soil hydraulic properties.

Seobi et al. (2005) found soil under perennial grass and tree buffers had lower bulk density and higher porosity than soil under row crop areas. They also concluded that after six years of establishing the buffers, soil under buffers can store more water and hence would have lower runoff and less sediment, nutrient, and herbicide losses. Similarly, Rachman et al. (2004) showed that areas under perennial grass hedges for more than ten years had lower bulk density and clay content and higher porosity and saturated hydraulic conductivity than areas under row crop cultivation for the same soil. Skaggs et al. (2006) studied the effects of forest management on saturated hydraulic conductivity $\left(\mathrm{K}_{\text {sat }}\right)$ and found $\mathrm{K}_{\text {sat }}$ values for a mature plantation forest were 20 to 30 times higher than values given in the soil survey for the study area. They attributed this deviation in $\mathrm{K}_{\text {sat }}$ values to the difference in land management.

These variations in soil hydraulic properties are probably caused by perennial vegetation compared to annual row crop management. This perennial vegetation increases soil porosity, which in turn strongly influences soil hydraulic properties (Seobi et al. 2005; Udawatta et al. 2008). Under perennial vegetation, the soil is not disturbed with tillage, which is unlike annual row crop management; this perennial management maintains better soil bulk density and hydraulic properties over the long term (van Dijck and van Asch 2002; Fuentes et al. 2004; Assouline 2006).

While management can affect soil properties through soil compaction and root processes, long-term management could have

Ashish Mudgal is a graduate student, and Stephen H. Anderson is a professor in the Department of Soil, Environmental, and Atmospheric Sciences, University of Missouri, Columbia, Missouri. Claire Baffaut is a hydrologist, Newell R. Kitchen is a soil scientist, and Edward J. Sadler is research leader in the USDA Agricultural Research Service Cropping System and Water Quality Research Unit, Columbia, Missouri. 
additional effects due to erosion and loss of the top soil layer. Soil erosion is critical for plant production when a topsoil silt loam layer becomes thinner and a subsoil high in clay content is exposed (Larson et al. 1983; Pierce et al. 1983; Scrivner et al. 1985). This is a typical feature of soils in Major Land Resource Area 113 (Central Claypan Area), where an argillic horizon high in clay content $(>50 \%)$ is overlaid by silt loam (Blanco-Canqui et al. 2002; Lerch et al. 2005). Removal of the siltloam layer due to erosion exposes the high clay content layer; Pierce et al. (1983) found that erosion of these types of soils disproportionately reduces crop productivity. Kitchen et al. (2005), in a study on claypan soils, found that crop yield is highly variable and could be better represented by topography and clay depth as measured using an electrical conductivity sensor than with an Order 1 Soil Survey (detailed soil survey of 1:5000 scale). Lerch et al. (2005) concluded from a study in claypan soils that long-term variability in soil loss was able to explain the patterns of soil quality, water quality, and crop yield. This loss of topsoil not only reduces crop productivity but also augments the detrimental impact on soil and water quality; Mudgal et al. (2008), in a simulation study, concluded that there is more probability of increased runoff and atrazine loss from areas with shallow claypan soils.

Jiang et al. (2007a) examined the impact of four conservation management systemsmulch till, no-till, CRP (Conservation Resource Program) and perennial hay-on soil hydraulic properties influenced by landscape position on claypan soils. They found that most of the effects of management were limited to the top $10 \mathrm{~cm} \mathrm{(3.9} \mathrm{in)} \mathrm{of} \mathrm{soil.}$ Below this depth, soil hydraulic properties were more dependent on the depth from the surface to the claypan. At the backslope position, which had the shallowest depth to claypan, they found the lowest $\mathrm{K}_{\text {sat }}$ in comparison to summit and footslope positions. They concluded from the four management practices that the use of perennial grasses improved soil hydraulic properties the most.

The objective of this study was to quantify the impact of two long-term management systems on soil water retention, pore-size distributions, bulk density, and saturated hydraulic conductivity. It has been hypothesized that for similar soils, differences in long-term management practices can have a significant impact on soil hydraulic properties. To evaluate this hypothesis, soil hydraulic

\section{Figure 1}

Location of study sites: Field $\left(39^{\circ} 13^{\prime} 4^{\prime \prime} \mathrm{N}, 92^{\circ} 7^{\prime} 12^{\prime \prime} \mathrm{W}\right)$, and Tucker Prairie ( $3^{\circ} 57^{\prime} 4^{\prime \prime N}$, 91०59'30"W).

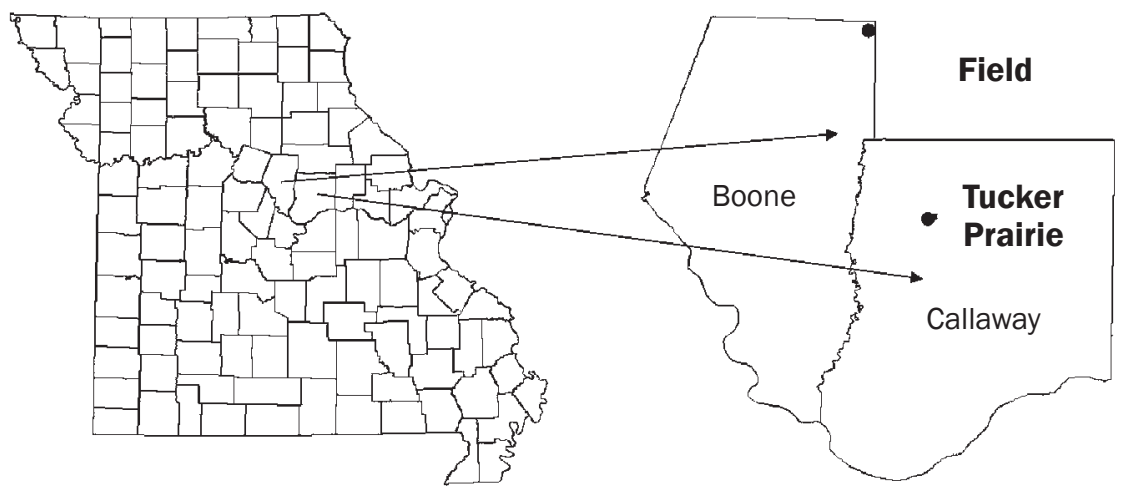

\section{Table 1}

Physical and chemical properties of typical soil profiles for Field (field under long-term row crop management) and Tucker Prairie (never been tilled) sites.

\begin{tabular}{|c|c|c|c|c|c|c|}
\hline Soil horizon & $\begin{array}{l}\text { Soil depth } \\
\text { (cm) }\end{array}$ & $\begin{array}{l}\text { Clay } \\
\left(\%\left[\mathrm{~g} \mathrm{~g}^{-1}\right]\right)\end{array}$ & $\begin{array}{l}\text { Silt } \\
\left(\%\left[\mathrm{~g} \mathrm{~g}^{-1}\right]\right)\end{array}$ & $\begin{array}{l}\text { CEC } \\
\left(\text { cmolc kg }^{-1}\right)\end{array}$ & $\begin{array}{l}\begin{array}{l}\text { Organic } \\
\text { carbon } \\
\left(\mathrm{g} \mathrm{kg}^{-1}\right)\end{array} \\
\end{array}$ & $\begin{array}{l}\mathrm{pH} \text { of } \\
\text { water }\end{array}$ \\
\hline \multicolumn{7}{|l|}{ Field } \\
\hline$A p$ & 0 to 24 & 14.0 & 81.9 & 13.6 & 8 & 4.9 \\
\hline $\mathrm{E}$ & 24 to 34 & 20.4 & 72.0 & 16.4 & 6 & 4.7 \\
\hline Bt1 & 34 to 45 & 54.0 & 43.4 & 37.8 & 9 & 4.7 \\
\hline $\mathrm{Bt} 2$ & 45 to 65 & 56.6 & 41.8 & 39.9 & 8 & 4.6 \\
\hline \multicolumn{7}{|c|}{ Tucker Prairie* } \\
\hline $\bar{A}$ & 0 to 20 & 18.9 & 74.3 & 19.3 & 36 & 5.2 \\
\hline$A E$ & 20 to 25 & 20.4 & 72.5 & 14.3 & 13 & 5.0 \\
\hline$E$ & 25 to 36 & 21.5 & 70.7 & 14.8 & 9 & 4.9 \\
\hline EB & 36 to 41 & 24.9 & 68.1 & 16.3 & 8 & 5.0 \\
\hline Bt1 & 41 to 56 & 50.6 & 46.7 & 33.0 & 11 & 4.8 \\
\hline
\end{tabular}

Note: $\mathrm{CEC}=$ cation exchange capacity.

* Source: Udawatta et al. 2008.

properties were compared between a field under row crop cultivation for over 100 years and a native prairie that has never been tilled. Comparison of soil hydraulic properties due to long-term soil erosion could help in understanding the impact of topsoil loss, especially in claypan areas.

\section{Materials and Methods}

Experimental Site. Two sites were selected (figure 1): one under long-term row crop management that has been under cultivation for more than 100 years (Field) and one under native prairie (Tucker Prairie [TP]) that has never been tilled (table 1). The Field site is located near the town of Centralia in central Missouri. Presently this site is managed by the USDA Agricultural Research
Service Cropping Systems and Water Quality Unit (Lerch et al. 2005).

The historical management records for the Field site were presented by Lerch et al. (2005). They found that during the earlier half of the 20th century, the most likely crops were corn and wheat under plow and disk tillage. During the later part of the century, plowing and disk tillage were continued, but the cropping system could be described with more confidence as corn, soybean, and grain sorghum. After 1991, the field was under uniform management with a corn-soybean rotation with mulch tillage.

Tucker Prairie is an untilled native prairie (Dahlman and Kucera 1965) that is also located in central Missouri and is under native vegetation. The major species 
found in the prairie include big blue stem (Andropogon genardi Vitman.), little blue stem (Schizachyrium scoparium Nash.), prairie dropseed (Sporobolus heterolepis [A. Gray]), and Indian grass (Sorghastrum nutans [L. J. Nash]) (Udawatta et al. 2008). Kucera et al. (1967) stated that the only source of soil disturbances in the prairie were microbial processes, small rodents, and insects other than fire.

Soils at both the sites are classified as Mexico silt loam (fine, smectitic, mesic Vertic Epiaqualfs). Mexico soils are mostly located on ridges or hillsides having slopes of $0 \%$ to $4 \%$ and are formed in loess over loamy sediments derived from glacial till. These soils are poorly drained, mainly due to the presence of an argillic claypan horizon that is 10 to $30 \mathrm{~cm}$ (3.9 to $12 \mathrm{in}$ ) deep below the surface (Ghidey and Alberts 1999). Table 1 shows that the Bt horizon at the Field site starts at approximately the $30 \mathrm{~cm}$ (12 in) soil depth, whereas at the TP site, this horizon starts after $40 \mathrm{~cm}$ (16 in) of soil, with the clay content in the Field site being slightly higher for its Bt horizon than for the TP site.

Soil Sampling and Analysis. Sampling was done during the summer of 2008 at both sites. Undisturbed soil cores of $7.6 \mathrm{~cm}$ ( 3 in) diameter and $7.6 \mathrm{~cm}$ length were taken using an intact core sampler to determine soil water retention, bulk density, and $\mathrm{K}_{\text {sat }}$. Six soil cores were sampled at $10 \mathrm{~cm}(3.9$ in) depth intervals, starting from the surface with six replicates per site. Once the samples were collected in aluminum rings, they were enclosed with two plastic covers on the top and bottom, labeled, and transported to the laboratory in wooden boxes. Soil samples were stored in a refrigerator at $4^{\circ} \mathrm{C}\left(39^{\circ} \mathrm{F}\right)$ until analyses were conducted.

Soil cores were taken from the refrigerator, covered with cheese cloth on the bottom, and then were saturated in a plastic tray. Once the samples were saturated, the gaps between the soil core and aluminum ring were sealed using a bentonite solution. The constant head method was used to measure $\mathrm{K}_{\text {sat }}$ (Klute and Dirksen 1986). If the flow rate of water through the soil core was less than $1 \mathrm{~mm} \mathrm{~h}^{-1}\left(0.039 \mathrm{in} \mathrm{hr}^{-1}\right), \mathrm{K}_{\text {sat }}$ was measured using the falling head method as described in Klute and Dirksen (1986). The electrical conductivity of the water was $0.68 \mathrm{dS} \mathrm{m}^{-1}$, and the sodium absorption ratio was 2.34 .

After $\mathrm{K}_{\text {sat }}$ measurements, soil water retention was determined at $0.0,-0.4,-1,-2.5,-5$,
-10 , and $-20 \mathrm{kPa}(0.0,-0.06,-0.15,-0.36$, $-0.73,-1.45$, and $-2.9 \mathrm{lb} \mathrm{in}^{-2}$ ) soil water pressures using Buchner funnels; the pressure plate method was used for lower soil water pressures at $-33,-100$, and $-1,500 \mathrm{kPa}(-4.8$, -14.5 , and $-217.6 \mathrm{lb}^{-2}$ ) (Klute and Dirksen 1986). Soil cores were then air dried and weighed. A subsample from each core was oven dried at $105^{\circ} \mathrm{C}\left(221^{\circ} \mathrm{F}\right)$ for 24 hours Bulk density was determined from air-dried samples corrected to an oven-dry weight.

Soil water retention data were used to estimate the van Genuchten parameters. The van Genuchten (1980) function describes the soil water retention curve (Lu et al. 2007) as

$\theta=\theta_{r}+\left(\theta_{s}-\theta_{r}\right)\left[1+(-\alpha h)^{n}\right]^{(1 / n-1)}$,

where $\theta$ is the volumetric water content, $\theta$ and $\theta$ are the residual and saturated water contents, respectively, and $h$ is the hydraulic head. The parameters $\alpha, n$, and $m(m=$ $1-1 / n)$ are fitting parameters. During the curve fittings, $\theta$, was always taken as zero, and $\theta$, values were used as measured in the laboratory. For all the soil samples, $\alpha$ and $n$ values were fitted using equation 1 with the RETC computer program (van Genuchten et al. 1991).

Soil water pressure data was used to estimate the effective pore size using the capillary rise equation (Jury et al. 1991). Pore sizes were divided into four different classes: macropores $(>1,000 \mu \mathrm{m}$ [ $>0.039 \mathrm{in}]$ effective diameter), coarse mesopores (60 to $1,000 \mu \mathrm{m}$ [0.0024 to $0.039 \mathrm{in}]$ effective diameter), fine mesopores (10 to $60 \mu \mathrm{m}$ [0.00039 to 0.0024 in] effective diameter), and micropores $(<10$ $\mu \mathrm{m}[<0.00039 \mathrm{in}]$ effective diameter) as were used in Rachman et al. 2004.

The year 2008 was an unusually wet year, which produced a perched water table at both sites during the summer. In June, a shallow water table technique was used to measure saturated hydraulic conductivity $\left(\mathrm{K}_{\text {sat }}\right)$. At both sites, nine to twelve replicate points were assessed using the auger hole method (Klute and Dirksen 1986).

Statistical Analysis. Analysis of variance (ANOVA) was performed using the General Linear Model (GLM) procedure (SAS Institute 1999) at the 95\% significance level to test differences between treatments (Field and TP), depths, and treatment by depth interactions. Significant differences between treatment or depth means were assessed by using least significant differences at the 95\% probability level (Duncan's LSD). For fitting the van Genuchten parameters, the coefficient of determination was used for assessing the fit with values above 0.85 .

\section{Results and Discussion}

Soil Water Retention Results. Treatment factors were significantly different at all soil water pressures except two, -20.0 and -33.0 $\mathrm{kPa}\left(-2.9\right.$ to $-4.8 \mathrm{lb} \mathrm{in}^{-2}$ ) (table 2 ). Soil water retention values, as a function of soil depth for all measured soil water pressures, were found to be different (table 2). Generally, soil water retention at pressures higher than -33 $\mathrm{kPa}\left(-4.8 \mathrm{lb} \mathrm{in}^{-2}\right)$ was greater for the first and sixth depths and was lower for the second and/or third depth. This can be attributed to variations in clay content throughout the profile (table 1). Interactions between treatment and depth were significant for all the soil water potentials. This was attributed to the differential clay content profile between the two sites.

Differences in soil water retention between the treatments for specific soil depths are shown in figure 2. For the TP treatment, soil water content was much higher than for the Field treatment for the first depth at soil water pressures less than $-20 \mathrm{kPa}(-2.9 \mathrm{lb}$ $\mathrm{in}^{-2}$ ). For the fourth depth (30 to $40 \mathrm{~cm}$ [12 to 16 in]), water content was higher at the Field site than at the TP site for all pressures. This was attributed to the claypan being at a shallower depth for the Field site because erosion has occurred to a greater extent with continuous cultivation.

At the fifth depth (40 to $50 \mathrm{~cm}[16$ to 20 in]), water contents for higher pressures were not different between the treatments. This result was attributed to these two treatments having similar clay content at the 40 to $50 \mathrm{~cm}$ depth (table 1). At the sixth depth (50 to $60 \mathrm{~cm}$ [20 to $24 \mathrm{in}]$ ), the soil water content trend showed the TP site had significantly higher water content than the Field site at all pressures. This was due to the clay content decreasing at this depth for the Field site, while the clay content remained high for the Tucker site. The claypan depth change is a result of the erosion that has taken place at the Field site compared to less erosion at the TP site.

van Genuchten Parameter Results. The soil water characteristics for the sites and depths of this study were well described by the van Genuchten relationship ( $r^{2}$ values $>$ 0.85). The fitted van Genuchten parameters 
Table 2

Soil water content means for treatments and depths along with analysis of variance (ANOVA) probability values $(P>F)$ over a range of soil water pressures for Field (field under long-term row crop management) and Tucker Prairie (never been tilled) sites.

\begin{tabular}{|c|c|c|c|c|c|c|c|c|c|c|}
\hline Statistic & \multicolumn{10}{|c|}{ Soil water pressure $(\mathrm{kPa})$} \\
\hline Mean & \multicolumn{10}{|c|}{ Volumetric water content $\left(\mathrm{m}^{3} \mathrm{~m}^{-3}\right)$} \\
\hline \multicolumn{11}{|l|}{ Treatment } \\
\hline Field & 0.509 & 0.479 & 0.464 & 0.448 & 0.435 & 0.423 & 0.409 & 0.383 & 0.303 & 0.185 \\
\hline TP & 0.570 & 0.541 & 0.516 & 0.487 & 0.460 & 0.440 & 0.419 & 0.374 & 0.278 & 0.147 \\
\hline 10 to 20 & 0.508 & 0.486 & 0.471 & 0.448 & 0.420 & 0.395 & 0.370 & 0.348 & 0.209 & 0.100 \\
\hline 20 to 30 & 0.501 & 0.489 & 0.473 & 0.443 & 0.413 & 0.389 & 0.368 & 0.348 & 0.248 & 0.130 \\
\hline 30 to 40 & 0.528 & 0.495 & 0.473 & 0.448 & 0.428 & 0.411 & 0.396 & 0.374 & 0.306 & 0.170 \\
\hline 40 to 50 & 0.533 & 0.493 & 0.473 & 0.463 & 0.460 & 0.453 & 0.443 & 0.396 & 0.338 & 0.233 \\
\hline 50 to 60 & 0.573 & 0.543 & 0.534 & 0.525 & 0.517 & 0.514 & 0.505 & 0.461 & 0.401 & 0.259 \\
\hline
\end{tabular}

for the treatments and soil depths are listed in table 3 . The $n$ values for both treatments were less than 2. The $\alpha$ values, which are the inverse of the air-entry potential (Fuentes et al. 2004), were always less than 0.2. The effects of soil depth on these parameters are illustrated in figure 3 . The $\alpha$ parameter was significantly higher for the TP site at the surface depth and was significantly lower for the fifth depth than at the Field site

Pore-Size Distribution Results. Longterm soil management treatments (TP and Field sites) had significant effects on coarse and fine mesopores (table 4). No significant effects were found for treatments on macropores.

Coarse and fine mesoporosity for the Field site were 0.044 and $0.053 \mathrm{~m}^{3} \mathrm{~m}^{-3}$ (0.044 and $0.053 \mathrm{in}^{3} \mathrm{in}^{-3}$ ) (table 4), respectively, values almost half those for the TP site of 0.081 and $0.086 \mathrm{~m}^{3} \mathrm{~m}^{-3}(0.081$ and $\left.0.086 \mathrm{in}^{3} \mathrm{in}^{-3}\right)$, respectively.

Pore-size classes significantly changed with soil depth (table 4). Least significant differences between treatments for different depths are shown in figure 4. Coarse and fine mesopores both were significantly higher for the TP site than for the Field site for the upper four and three soil depths, respectively. For deeper depths, the impact of soil structure decreased between the treatments. Significant differences in micropores were found at only the fourth and sixth depths. The higher amount of micropores in the fourth depth and the lower amount of micropores in the sixth depth for the Field site than for the TP site is due to the shallower clay depth found at the Field site (table 1). After a depth of $50 \mathrm{~cm}$ (20 in), the clay content at the Field site starts to decrease, while it is still increasing at the TP site. This difference in clay content further supports the argument of greater topsoil loss from the Field site, which has been under cultivation for over 100 years, compared to the native prairie, which has never been tilled (Lerch et al. 2005).

Bulk Density Results. Bulk density was found to be different between the treatments, soil depths, and also for the interaction between treatment and soil depth (table 4). Bulk density was higher for the Field site than for the TP site.

Bulk density was significantly different for all the depths between both treatments, except for the third depth $(20$ to $30 \mathrm{~cm}$ [7.9 to 12 in]) (figure 5). Due to the higher root density at the TP site, the bulk density at the soil surface was less than $1 \mathrm{~g} \mathrm{~cm}^{-3}\left(62.4 \mathrm{lb} \mathrm{ft}^{-3}\right)$. After the first depth, the effect of roots began to diminish, and the bulk density increased for the TP site. After the fourth depth, there was increase in clay content, which resulted in a lower bulk density. At the Field site, the bulk density was lowest for the fourth depth (30 to $40 \mathrm{~cm}$ [12 to $16 \mathrm{in}$ ]), where the clay percentage was the highest. After this depth, bulk density increased with a reduction in clay content.
Saturated Hydraulic Conductivity Results. There were differences in $\mathrm{K}_{\text {sat }}$ between treatments, soil depths, and for treatment and depth interactions (table 4). The $\mathrm{K}_{\text {sat }}$ was higher for the TP site than the Field site averaged across soil depths (table 4). The $\mathrm{K}_{\text {sat }}$ value for the TP site was almost 20 times higher than the Field site values, even for the same soil series. Thus, due to the changes in long-term management, there were considerable differences in $\mathrm{K}_{\text {sat. }}$. These differences were more extreme than found in the literature on similar soils. Seobi et al. (2005) found that $\mathrm{K}_{\text {sat }}$ was 14 times higher for agroforestry buffers than for row crop management. In another study by Fuentes et al. (2004), researchers found that $\mathrm{K}_{\text {sat }}$ values of soils under native prairie were almost 10 times higher than of soils under conventional tillage and no-till management.

The $\mathrm{K}_{\text {sat }}$ values for the TP site were always higher than the Field site (figure 6), although significant differences occurred only in the first depth due to the high variability of this property. The $\mathrm{K}_{\text {sat }}$ value for the surface soil at the TP site was almost 57 times higher than at the Field site. After the third depth, $\mathrm{K}_{\mathrm{sat}}$ at the Field site drops by an order of magnitude, from 5 to $0.3 \mathrm{~mm} \mathrm{~h}^{-1}$ (0.197 to $0.012 \mathrm{in} \mathrm{hr}^{-1}$ ). This might be due to the abrupt change in clay percentage in the soil at the Field site. A similar drop of $\mathrm{K}_{\mathrm{sat}}$ for the TP site was found to occur after the fourth depth, from 17 to

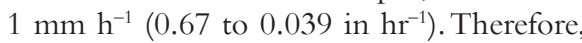
at the Field site, the downward movement 


\section{Figure 2}

Effects of management on soil water retention for the following depths: (a) o to $10 \mathrm{~cm}$, (b) 10 to $20 \mathrm{~cm}$, (c) 20 to $30 \mathrm{~cm}$, (d) 30 to $40 \mathrm{~cm}$, (e) 40 to $50 \mathrm{~cm}$, and (f) 50 to $60 \mathrm{~cm}$. Values are for Field (field under long-term row crop management) and Tucker Prairie (never been tilled) sites.

Bars indicate least significant difference ( 0.05$)$ values for a specific soil water pressure when significant differences occurred; these values are the same for all depths.
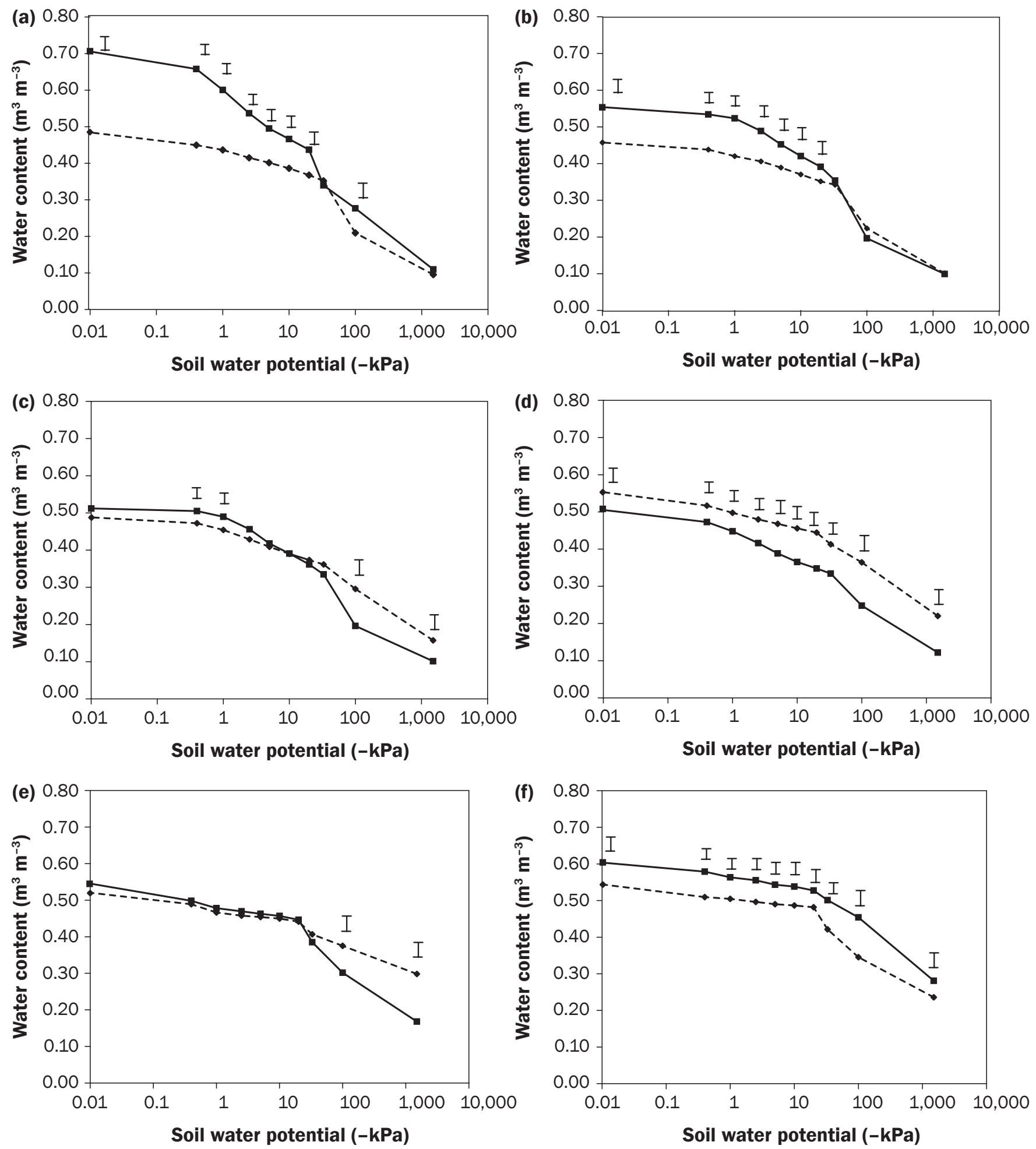

Legend $\quad-\bullet-$ Field $\rightarrow$ Tucker Prairie 
Table 3

Fitted van Genuchten parameters as a function of depth for the Field (field under long-term row crop management) and Tucker Prairie (never been tilled) sites.

\begin{tabular}{|c|c|c|c|c|c|c|}
\hline \multirow{2}{*}{$\begin{array}{l}\text { Soil depth } \\
\text { (cm) }\end{array}$} & \multicolumn{6}{|l|}{ Fitted parameters* } \\
\hline & $\theta_{\mathrm{s}}\left(\mathrm{cm}^{3} \mathrm{~cm}^{-3}\right)$ & $n+$ & $\alpha\left(\mathrm{cm}^{-1}\right) \dagger$ & $\theta_{\mathrm{s}}\left(\mathrm{cm}^{3} \mathrm{~cm}^{-3}\right)$ & $n \dagger$ & $\alpha\left(\mathrm{cm}^{-1}\right) \dagger$ \\
\hline 10 to 20 & $0.463(0.440,0.496)$ & $1.242(1.182,1.289)$ & $0.020(0.012,0.052)$ & $0.554(0.491,0.631)$ & $1.339(1.241,1.568)$ & $0.025(0.004,0.070)$ \\
\hline 20 to 30 & $0.491(0.454,0.543)$ & $1.165(1.108,1.220)$ & $0.044(0.016,0.134)$ & $0.512(0.488,0.543)$ & $1.274(1.227,1.303)$ & $0.021(0.011,0.035)$ \\
\hline 50 to 60 & $0.544(0.516,0.623)$ & $1.153(1.135,1.181)$ & $0.015(0.011,0.024)$ & $0.604(0.590,0.624)$ & $1.135(1.103,1.162)$ & $0.012(0.006,0.021)$ \\
\hline
\end{tabular}

Notes: $\theta_{r}$ (residual water content) value was set to zero. $\theta_{s}=$ saturated water content.

* Values in parentheses are minimum and maximum values.

$\dagger \alpha$ and $n$ are Van Genuchten fitted parameters. $n$ is dimensionless.

of water reduces to a very low rate after 30 $\mathrm{cm}$ (12 in), and at the TP site, this clay barrier for restricted downward movement of water occurs after $50 \mathrm{~cm}$ (20 in). At the TP site, there is a thicker silt loam soil profile that can absorb more water than at the Field site; hence there will be a greater probability of more surface runoff occurring from the Field site (Mudgal et al. 2008).

Soil Water Retention Discussion. The Mexico soil has an argillic horizon underneath the silt loam surface horizon, and the depth of the argillic horizon dominates many major hydrologic processes (Mudgal et al. 2008). These processes are dependent on soil hydraulic properties. Variations in soil hydraulic properties were associated with variation in clay content and depth to argillic horizon. The mean soil water contents for all soil water pressures greater than $-33 \mathrm{kPa}$ $\left(-4.8 \mathrm{lb} \mathrm{in}^{-2}\right)$ at the TP site averaged across all soil depths were always higher than values for the Field site but were lower for other pressures (table 2). This might be attributed to the higher clay content for more depths at the Field site (table 1). A similar trend was found by Scott and Wood (1989) in a study in silt loam (Albaqualf) soils; they found that for surface soil under cultivation for 30 years and a virgin prairie, soil water retention at -30 and $-1,500 \mathrm{kPa}\left(-4.4\right.$ to $\left.-217.6 \mathrm{lb} \mathrm{in}^{-2}\right)$ were not significantly different, whereas water retention was significantly different for other pressures (higher water pressures).

Differences in soil water retention for the first three depths could be attributed to management variations, but for deeper depths, differences were more dependent on clay content. We presume the differences in soil water retention for upper layers were due to the higher root density of the perennial

\section{Figure 3}

Effects of management and depth on fitted van Genuchten parameters $\alpha$ and $n$. Values are for Field (field under long-term row crop management) and Tucker Prairie (never been tilled) sites. Bars indicates least significant difference (0.05) values.
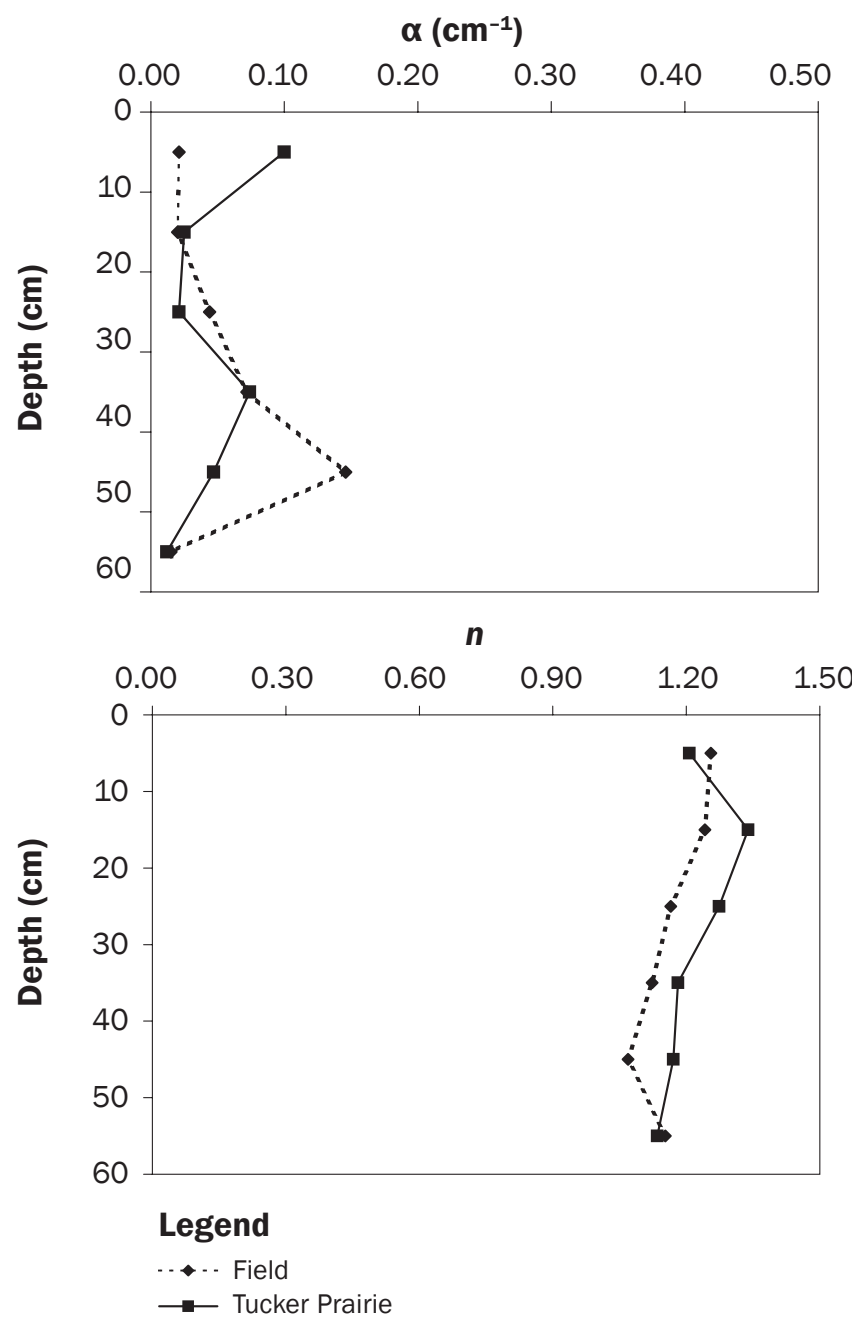
Table 4

Treatment and depth means along with analysis of variance (ANOVA) probability values $(P>F)$ for saturated hydraulic conductivity $\left(K_{\text {sat }}\right)$, bulk density (BD), macroporosity, coarse mesoporosity, fine mesoporosity, and microporosity for the Field (field under long-term row crop management) and Tucker Prairie (never been tilled) sites.

\begin{tabular}{|c|c|c|c|c|c|c|}
\hline & $\begin{array}{l}\text { Macroporosity } \\
(>1,000 \mu \mathrm{m}) \\
\left(\mathrm{cm}^{3} \mathrm{~cm}^{-3}\right)\end{array}$ & $\begin{array}{l}\text { Coarse mesoporosity } \\
(60 \text { to } 1,000 \mu \mathrm{m}) \\
\left(\mathrm{cm}^{3} \mathrm{~cm}^{-3}\right)\end{array}$ & $\begin{array}{l}\text { Fine mesoporosity } \\
(10 \text { to } 60 \mu \mathrm{m}) \\
\left(\mathrm{cm}^{3} \mathrm{~cm}^{-3}\right)\end{array}$ & $\begin{array}{l}\text { Microporosity } \\
(<10 \mu \mathrm{m}) \\
\left(\mathrm{cm}^{3} \mathrm{~cm}^{-3}\right) \\
\end{array}$ & $K_{\text {sat }}\left(\mathrm{mm} \mathrm{h}^{-1}\right)$ & $\mathrm{BD}\left(\mathrm{g} \mathrm{cm}^{-3}\right)$ \\
\hline \multicolumn{7}{|l|}{ Treatment } \\
\hline Field & 0.030 & 0.044 & 0.053 & 0.383 & 4.313 & 1.350 \\
\hline Tucker Prairie & 0.030 & 0.081 & 0.086 & 0.374 & 87.66 & 1.131 \\
\hline \multicolumn{7}{|l|}{ Depth (cm) } \\
\hline 0 to 10 & 0.042 & 0.106 & 0.103 & 0.345 & 175.9 & 1.128 \\
\hline 10 to 20 & 0.023 & 0.066 & 0.073 & 0.348 & 62.79 & 1.304 \\
\hline 20 to 30 & 0.013 & 0.076 & 0.066 & 0.348 & 21.49 & 1.292 \\
\hline 30 to 40 & 0.033 & 0.065 & 0.054 & 0.374 & 12.58 & 1.242 \\
\hline 40 to 50 & 0.039 & 0.036 & 0.064 & 0.396 & 3.160 & 1.273 \\
\hline 50 to 60 & 0.030 & 0.027 & 0.055 & 0.461 & 0.020 & 1.206 \\
\hline \multicolumn{7}{|l|}{$\overline{\text { ANOVA }(P>F)}$} \\
\hline Treatment & 0.8541 & $<0.0001$ & $<0.0001$ & 0.2015 & 0.0004 & $<0.0001$ \\
\hline Depth & 0.0119 & $<0.0001$ & $<0.0001$ & $<0.0001$ & $<0.0001$ & $<0.0001$ \\
\hline $\begin{array}{l}\text { Treatment } \\
\text { by depth }\end{array}$ & 0.5443 & $<0.0001$ & $<0.0001$ & $<0.0001$ & $<0.0001$ & $<0.0001$ \\
\hline
\end{tabular}

grasses and forbs, which improved soil structure in the soil surface layers for the native prairie site (TP) compared to annual cultivation for the Field site. Fuentes et al. (2004) found similar results with soils under native prairie having better soil structure than fields under cultivation. Soil water content for the TP site was significantly higher at all pressures above $-33 \mathrm{kPa}\left(-4.8 \mathrm{lb} \mathrm{in}^{-2}\right)$ for the top two soil depths; this was attributed to better root development in the TP site and better soil structure near the surface.

Another noticeable feature with the water retention data is that the curves for pressures greater than $-20 \mathrm{kPa}\left(-2.9 \mathrm{lb} \mathrm{in}^{-2}\right)$ appear to be relatively unchanged with soil depth for the Field site (figure 2). This is likely due to several factors. In the upper two soil depths, traffic compaction has reduced the porosity over time compared to the native prairie site. In addition, reductions in organic matter (table 1) at shallow depths due to annual tillage and cultivation have occurred at the Field site for the past 100 years. For the third depth, the effects of cultivation management on water retention are less pronounced (figure 2). For the fourth depth, water retention at the Field site is higher due to differences in clay content in the profile compared to the prairie site (differential erosion). For the fifth depth, water retention values are similar due to similar levels of clay content (prairie increasing in clay and field site decreasing in clay). By the sixth depth, the clay content has decreased for the Field site and is now at a maximum for the TP site; the effects on water retention can be observed in figure 2 .

van Genuchten Parameter Discussion. The $n$ values found in present study were in accordance with the values found by Ippisch et al. (2005); they also found $n$ value ranging from 1 to 2 for fine textured soils. Statistical comparisons for $\alpha$ and $n$ values between the treatments and soil depths are shown in figure 3. No general trend was found, but the $\alpha$ parameter was significantly higher for the TP site at the surface depth and significantly lower for the fifth depth than at the Field site. These differences are attributed in part to those discussed earlier in the water retention section.

Pore-Size Distribution Discussion. Results from the current study were similar to those found by Seobi et al. (2005) in a study near Novelty, Missouri. They did not find any significant differences in macroporosity between soils under row crop management and agroforestry buffers for a Putnam silt loam (claypan soil) using similar measurement techniques to those in the present study. Other researchers using a different method have found differences (Udawatta et al. 2008). Using x-ray computed tomography, Udawatta et al. (2008) in similar soils (Epiaqualfs) found significantly higher levels of macroporosity $(>1,000 \mu \mathrm{m}$ [>0.039 in] effective diameter) for native prairie and CRP (Conservation Reserve
Program) land than for soils under row crop cultivation. Computed tomography methods may be better suited to detecting differences in macroporosity than estimates from water retention curves (Gantzer and Anderson 2002). However, the computed tomography method does not provide good estimates for the full range of mesopores.

Similarly, the management effect was visible for pore-size distribution. The significant difference was found between coarse and fine mesopores for the upper three soil depths between the two sites; this effect can be attributed to the influence of past compaction for the Field site and better structure for the TP site. As found in the TP site, major vegetation included native grasses and forbs that have a more shallow depth distribution of roots than does tree vegetation (Udawatta and Henderson 2003; Seobi et al. 2005). The variations in micropores were more dominated by differential clay content, and, therefore, they were significantly different at depths where clay content at the two sites was distinct, as was explained in the results section.

Bulk Density Discussion. The impact of long-term management was clearly visible on bulk density results. These differences can be attributed not only to vehicular traffic at the Field site but also to tillage. Rousseva et al. (1988) and Or et al. (2000) found that after tillage operations, cycles of wetting and drying might cause an increase in soil bulk density due to reconsolidation. The differ- 


\section{Figure 4}

Effects of management and depth on porosity for selected pore size classes: (a) macropores ( $\$ 1,000 \mu \mathrm{m}$ diameter), (b) coarse mesopores (6o to $1,000 \mu \mathrm{m}$ diameter), (c) fine mesopores, (10 to $60 \mu \mathrm{m}$ diameter), and (e) micropores ( $10 \mu \mathrm{m}$ diameter). Values are for Field (field under long-term row crop management) and Tucker Prairie (never been tilled) sites. Bars indicates least significant difference (0.05) values.

(a)

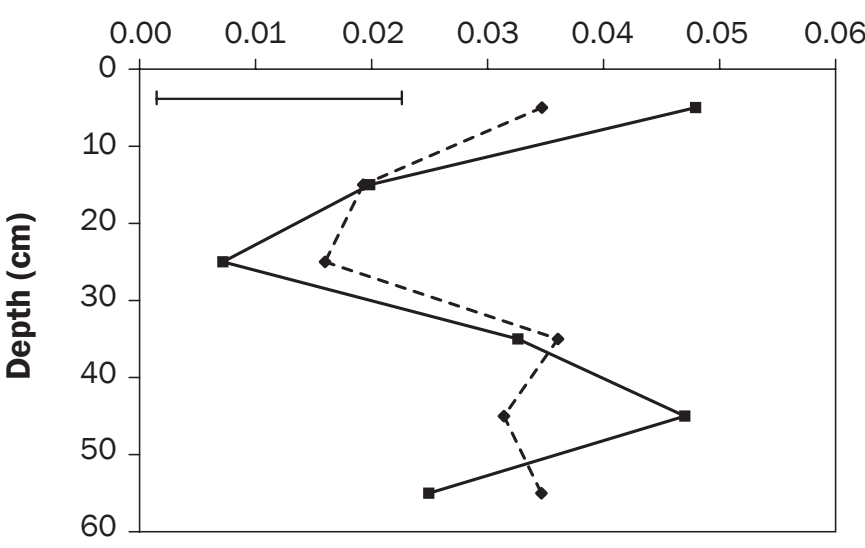

(c)

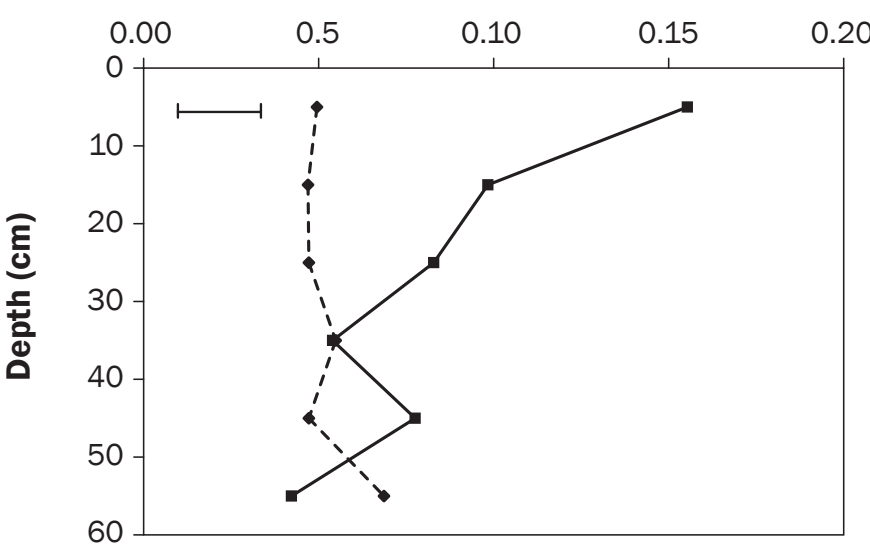

(b)

\section{Coarse mesopores $\left(\mathrm{m}^{3} \mathrm{~m}^{-3}\right)$}

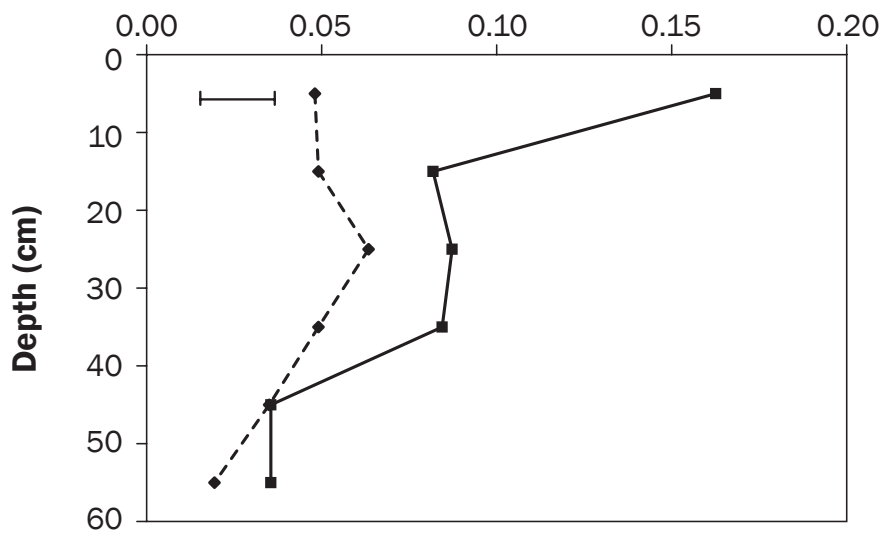

(d) Micropores $\left(\mathrm{m}^{\mathbf{3}} \mathrm{m}^{-\mathbf{3}}\right)$

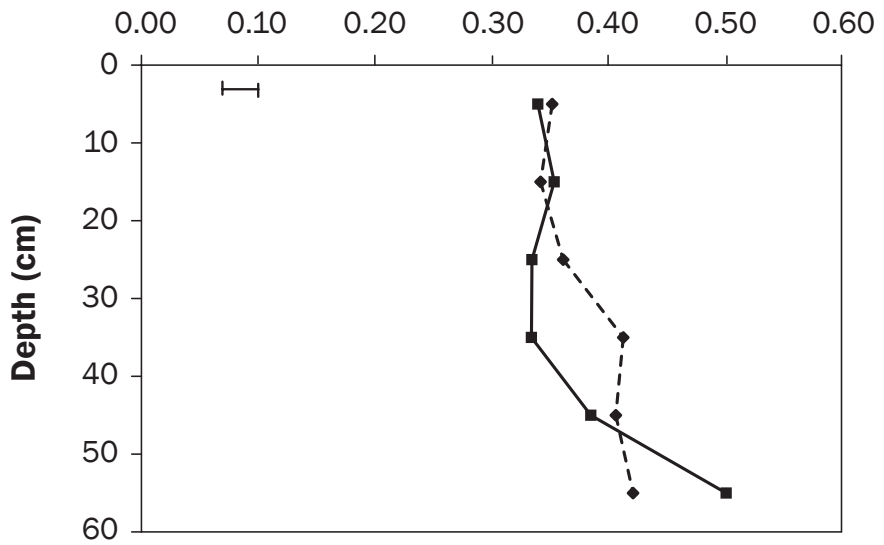

\section{Legend}

- - Field

$\rightarrow$ Tucker Prairie

ences in bulk density due to soil depth were mainly due to differences in structure and texture. The lowest bulk density was found in the first depth for the TP site, which could possibly be attributed to higher root density. The maximum bulk density was found for the Field site in the second depth. The lowest value for the Field site was found in the fourth depth and for the TP site was found in the sixth depth (with the exception of the first depth). These low values were found where the maximum expression of smectitic clays was encountered. Similar trends for bulk density were found by Jiang et al. (2007a). For the 0 to $10 \mathrm{~cm}$ depth (0 to 3.9 in), Jiang et al. found the CRP treatment had the lowest bulk density $\left(1.07 \mathrm{~g} \mathrm{~cm}^{-3}[67 \mathrm{lb}\right.$ $\left.\mathrm{ft}^{-3} \mathrm{]}\right)$, and the mulch till had the highest (1.25 $\mathrm{g} \mathrm{cm}^{-3}$ [78 lb ft ${ }^{-3}$ ) (Jiang et al. 2007a). They concluded that the management effect was limited only to this upper depth with deeper effects dominated by the clay content of the specific horizons.

Saturated Hydraulic Conductivity Discussion. The differences in $\mathrm{K}_{\text {sat }}$ values for the top depths were more dependent on soil structure variations, which were affected by land management. The $\mathrm{K}_{\text {sat }}$ differences for lower depths were due to distinction in clay content. Jiang et al. (2007a) did a study in similar soils (Epiaqualfs) that compared soil hydraulic properties among four different management systems and three landscape positions. They inferred that the differential claypan depth is a controlling factor on soil hydraulic properties. They found $\mathrm{K}_{\mathrm{sat}}$ differences were strongly affected by management at the backslope position, where the claypan was shallowest compared to other landscape positions. At the summit and footslope landscape positions, they did not find significant differences due to management. The present study did not evaluate the effects of landscape position but found substantially different $\mathrm{K}_{\text {sat }}$ values as affected by long-term management. 


\section{Figure 5}

Effects of management and depth on bulk density (BD). Values are for Field (field under longterm row crop management) and Tucker Prairie (never been tilled) sites. The bar indicates the least significant difference $(0.05)$ value.

\section{$\mathrm{BD}\left(\mathrm{g} \mathrm{cm}^{-3}\right)$}

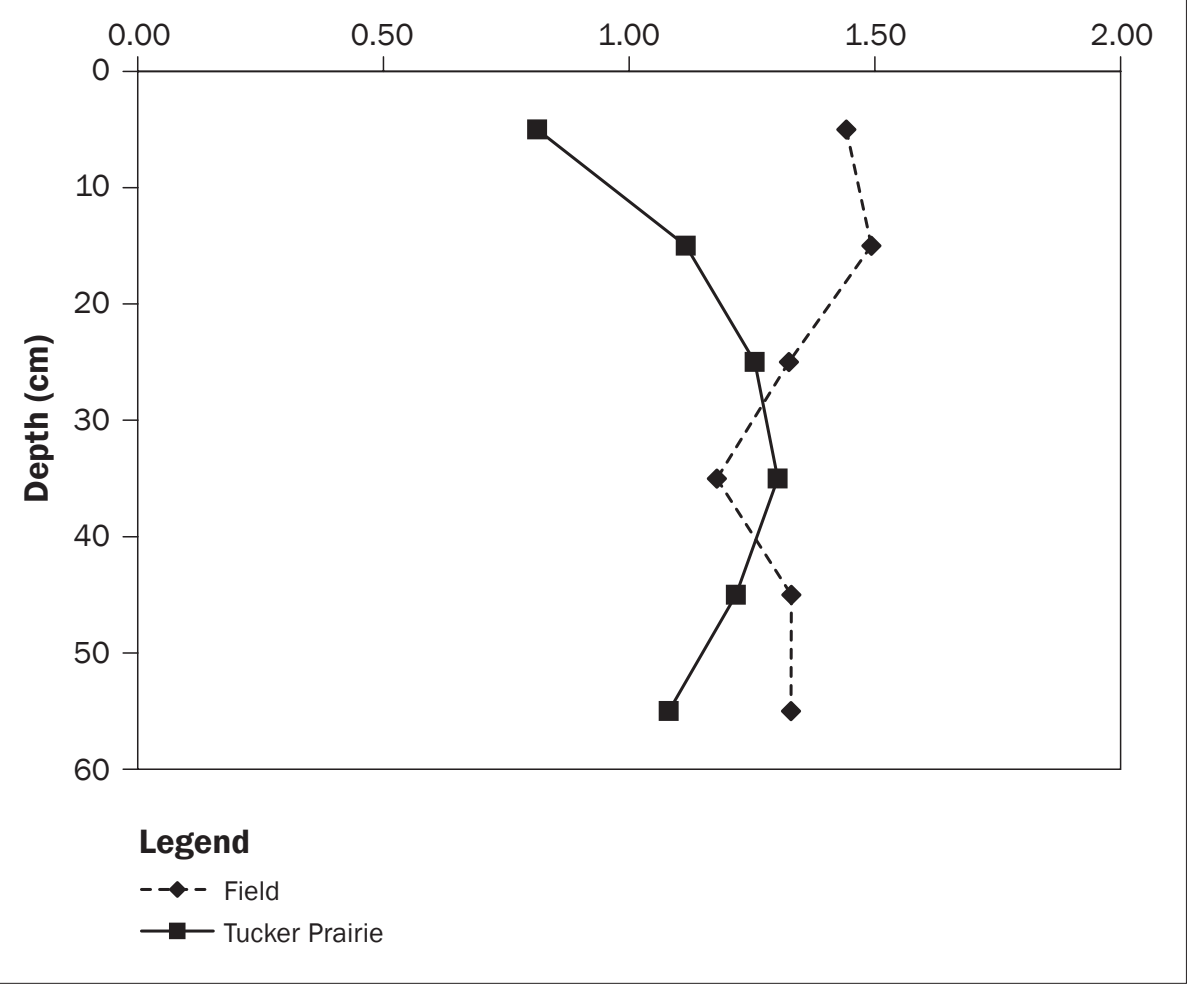

Table 5

Comparison of saturated hydraulic conductivity $\left(\mathrm{K}_{\mathrm{sat}}\right)$ values measured by auger hole and core sampling methods for the Field (field under long-term row crop management) and Tucker Prairie (never been tilled) sites.

\begin{tabular}{|c|c|c|c|}
\hline \multirow[b]{2}{*}{ Replicate points* } & \multirow[b]{2}{*}{ Depth $(\mathrm{cm}) \dagger$} & \multicolumn{2}{|l|}{$\underline{\mathbf{K}_{\text {sat }}}$} \\
\hline & & $\begin{array}{l}\text { Auger hole } \\
\left(\mathrm{mm} \mathrm{h}^{-1}\right) \ddagger\end{array}$ & $\begin{array}{l}\text { Core sampling } \\
\left(\mathrm{mm} \mathrm{h}^{-1}\right) \S\end{array}$ \\
\hline \multicolumn{4}{|l|}{ Field } \\
\hline 1 & 0 to 35 & 3.43 & 1.21 \\
\hline 2 & 1 to 35 & 4.74 & 5.84 \\
\hline 3 & 2 to 42 & 6.79 & 9.38 \\
\hline 4 & 2 to 40 & 5.10 & 2.14 \\
\hline \multicolumn{4}{|l|}{ Tucker Prairie } \\
\hline 1 & 5 to 40 & 72.5 & 65.4 \\
\hline 2 & 5 to 43 & 32.1 & 18.4 \\
\hline 3 & 12 to 42 & 92.9 & 41.2 \\
\hline 4 & 12 to 45 & 71.0 & 43.2 \\
\hline 5 & 6 to 50 & 46.9 & 7.75 \\
\hline 6 & 18 to 43 & 73.7 & 35.0 \\
\hline \multicolumn{4}{|c|}{ * Six replicate points chosen for sampling in Mexico silt loam soil. } \\
\hline \multicolumn{4}{|c|}{$\begin{array}{l}\dagger \text { Depth from water table to the bottom of hole used to measure } \mathrm{K}_{\text {sat }} \text { by auger hole method. } \\
\text { † Geometric mean } \mathrm{K}_{\text {sat }} \text { of two holes per replicate point. }\end{array}$} \\
\hline \multicolumn{4}{|c|}{$\S$ Effective $\mathrm{K}_{\text {sat }}$ for soil depths corresponding to auger hole method. } \\
\hline
\end{tabular}

The $\mathrm{K}_{\text {sat }}$ values measured by the auger hole method were not significantly different compared to values of $\mathrm{K}_{\mathrm{sat}}$ measured by the core sampling method (table 5). The average value for the Field site was $5.02 \mathrm{~mm} \mathrm{~h}^{-1}$ (0.198 in $\mathrm{hr}^{-1}$ ), while the value for the TP site was $62.9 \mathrm{~mm} \mathrm{~h}^{-1}\left(2.48 \mathrm{in} \mathrm{hr}^{-1}\right)$. The auger hole method measures a horizontal saturated hydraulic conductivity, while the core sampling method measures a vertical conductivity. Therefore, it can be concluded that $\mathrm{K}_{\text {sat }}$ was isotropic for these two sites.

The SSURGO (Soil Survey Geographic Database) (USDA NRCS 2008) database is one of the most common databases for acquiring soil properties in the United States. This database provides the values of soil parameters in ranges. The value of $\mathrm{K}_{\text {sat }}$ for Mexico silt loam in the database is

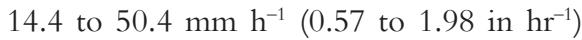
for the surface layer. In the present study, $\mathrm{K}_{\text {sat }}$ at the Field site was $5.55 \mathrm{~mm} \mathrm{~h}^{-1}(0.22$ in $\mathrm{hr}^{-1}$ ), which is $62 \%$ lower than the lowest value given in SSURGO for the surface soil. The $\mathrm{K}_{\mathrm{sat}}$ for the TP site surface layer was $316 \mathrm{~mm} \mathrm{~h}^{-1}$ (12.4 in $\left.\mathrm{hr}^{-1}\right)$, almost six times higher than the highest $\mathrm{K}_{\text {sat }}$ value given in SSURGO. This shows that the long-term management has changed $\mathrm{K}_{\text {sat }}$ properties to a larger extent than what could be expected from the range of values given in SSURGO. The $\mathrm{K}_{\mathrm{sat}}$ values are especially sensitive parameters of hydrologic simulation models when permeability is low or when there is a restrictive layer (Mudgal et al. 2008) and variation to this degree could significantly affect the output of studies predicting future impacts of different conservation practices on soil and water quality.

\section{Summary and Conclusions}

A study was conducted to quantify and compare the effects of long-term soil and crop management on soil hydraulic properties: soil water retention, pore-size distribution, bulk density, and $\mathrm{K}_{\mathrm{sat}}$. Two different management systems were selected: a native prairie that has never been tilled (Tucker Prairie [TP]) and a field that has been under row crop cultivation for more than 100 years (Field). Measured soil water retention curves showed that the Field site had lower soil water content for all pressures above $-33 \mathrm{kPa}(-4.8 \mathrm{lb}$ $\mathrm{in}^{-2}$ ), but for pressures at and below $-33 \mathrm{kPa}$ $\left(-4.8 \mathrm{lb} \mathrm{in}^{-2}\right)$, water content was higher at the TP site for the top two soil layers (0 to 10 $\mathrm{cm}$ and 10 to $20 \mathrm{~cm}$ [0 to 3.9 in and 3.9 to 
7.9 in]). Coarse (60 to $1,000 \mu \mathrm{m}[0.0024$ to $0.039 \mathrm{in}$ ] effective diameter) and fine mesoporosity (10 to $60 \mu \mathrm{m}[0.00039$ to 0.0024 in] effective diameter) values were lower for the Field site $\left(0.044\right.$ and $0.053 \mathrm{~m}^{3} \mathrm{~m}^{-3}$ [0.044 and $\left.0.053 \mathrm{in}^{3} \mathrm{in}^{-3}\right]$ ) and were almost half those for the TP site $\left(0.081\right.$ and $0.086 \mathrm{~m}^{3}$ $\mathrm{m}^{-3}\left[0.081\right.$ and $\left.\left.0.086 \mathrm{in}^{3} \mathrm{in}^{-3}\right]\right)$. Bulk density at the TP site for the surface soil (0 to 10 $\mathrm{cm}$ [0 to $3.9 \mathrm{in}])$ was $0.81 \mathrm{~g} \mathrm{~cm}^{-3}(50.6 \mathrm{lb}$ $\left.\mathrm{ft}^{-3}\right)$, which was two-thirds of the value at the Field site $\left(1.44 \mathrm{~g} \mathrm{~cm}^{-3}\left[89.9 \mathrm{lb} \mathrm{ft}^{-3}\right]\right)$. Bulk density at the TP site was significantly different than at the Field site for all except for the third depth (20 to $30 \mathrm{~cm}$ [7.9 to $12 \mathrm{in}]$ ). Saturated hydraulic conductivity $\left(\mathrm{K}_{\mathrm{sat}}\right)$ was almost 57 times higher at the TP site (316

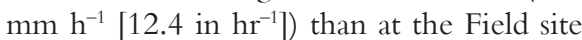
$\left(5.55 \mathrm{~mm} \mathrm{~h}^{-1}\left[0.219 \mathrm{in} \mathrm{hr}^{-1}\right]\right)$. This difference was likely caused by the differences in porosity and bulk density.

Variations in soil hydraulic properties could be explained by the differences in land cover and management (compaction, tillage) but also by the loss of topsoil and the thinning of the layer above the claypan. Extensive agricultural practices over the last 100 years at the Field site have reduced the topsoil by almost 20 to $30 \mathrm{~cm}$ (7.9 to $12 \mathrm{in}$ ) in comparison to the TP site that has never been tilled. The problem is likely to get worse as time progresses since higher bulk density, lower soil water capacity, and lower hydraulic conductivity increase the runoff potential and soil erosion. Therefore, it is expected that surface runoff and associated pollutant loads will be higher for the Field treatment than for the TP treatment.

Thus, loss of productivity and increased environmental impacts are likely to be more pronounced in those areas that are eroded. As found by Jiang et al. (2007a), fields could be delineated by landscape position, and conservation management could be targeted to more vulnerable landscapes. In addition, apparent electrical conductivity can be used to quantify variations in depth to claypan throughout fields, and these data can be used to predict variations in hydraulic properties (Jiang et al. 2007b).

Selection of various soil and water conservation practices and their efficiency depends upon soil hydraulic properties. This study concludes that soil hydraulic properties are significantly different for the same soil series when fields are under substantially different management. Therefore, soil hydraulic

\section{Figure 6}

Effects of management and depth on saturated hydraulic conductivity $\left(\mathrm{K}_{\text {sat }}\right)$. Values are for Field (field under long-term row crop management) and Tucker Prairie (never been tilled) sites. The least significant difference (0.05) values is listed on the graph due to log scale.
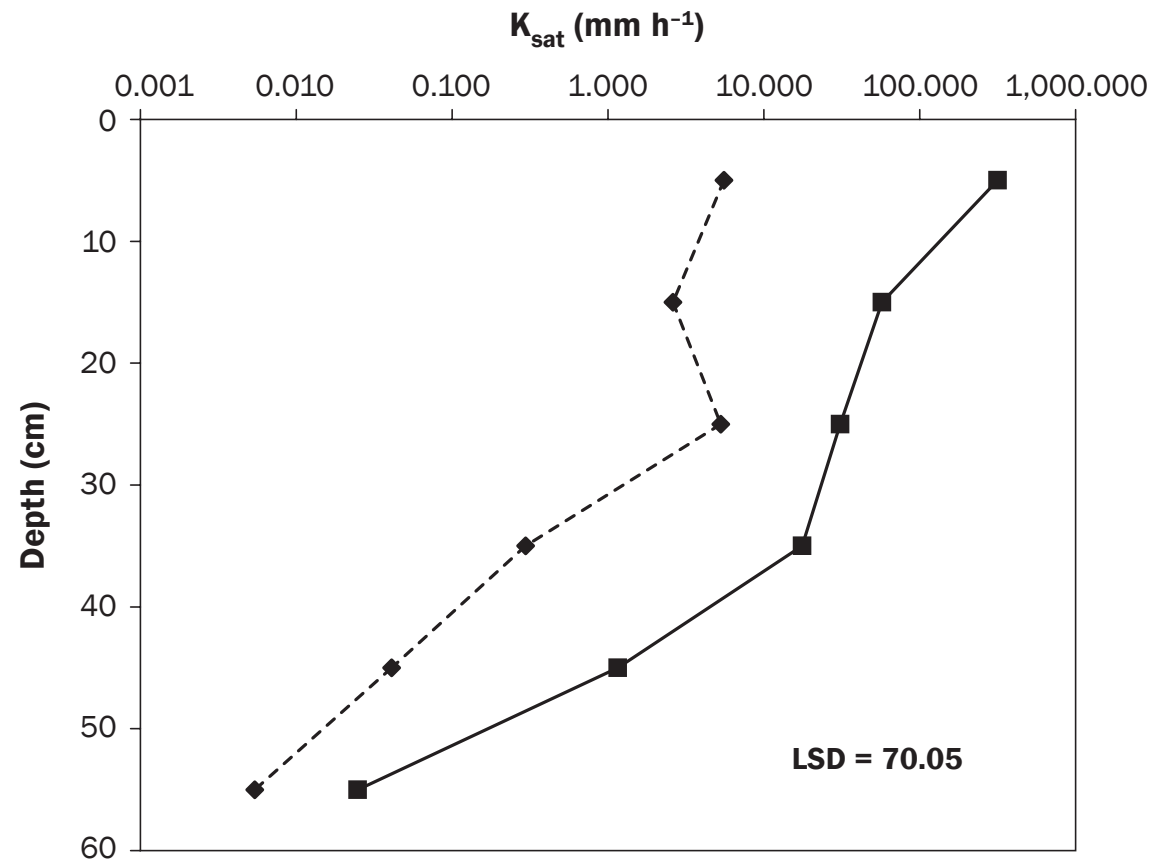

\section{Legend}

- - - - Field

$\longrightarrow$ Tucker Prairie

Note: $L S D=$ least significant difference.

parameters used for predictive purposes should be adjusted based on soil management in addition to soil mapping units.

\section{References}

Arriaga, FJ., and B. Lowery. 2003. Corn production on an eroded soil: Effects of total rainfall and soil water storage. Soil and Tillage Research 71:87-93.

Assouline, S. 2006. Modeling the relationship between soil bulk density and the water retention curve.Vadose Zone Journal 5(2):554-563.

Baer, J.U., and S.H. Anderson. 1997. Landscape effects on desiccation cracking in an Aqualf. Soil Science Society America Journal 61:1497-1502.

Beven, K., and P. Germann. 1982. Macropores and water flow in soils. Water Resource Research 18:1311-1325.

Blanco-Canqui, H., C.J. Gantzer, S.H.Anderson, E.E.Alberts, and F. Ghidey. 2002. Saturated hydraulic conductivity and its impact on simulated runoff for claypan soils. Soil Science Society America Journal 66:1596-1602.

Cadisch, G., P. Willington, D. Suprayogo, D.C. Mobbs, M. van Noordwijk, and E.C.Rowe. 2004. Catching and competing for mobile nutrients in soil. In Below Ground Interaction in Tropical Agroecosystems, ed. M. van Noordwijk, 171192. Cambridge, MA: CABI Publications.

Dahlman, R.C., and C.L. Kucera. 1965. Root productivity and turnover in native prairie. Ecology 49:1199-1203

Duriancik, F.L., D. Bucks, J.P. Dobrowolski, T. Drewes, S.D. Eckles, L. Jolley, R.L. Kellog, D. Lund, J.R. Makuch, M.P. O’Neill, C.A. Rewa, M.R. Walbridge, R. Parry, and M.A. Weltz. 2008. The first five years of the Conservation Effects Assessment Project. Journal of Soil and Water Conservation 63(6):185A-197A, doi:10.2489/jswc.63.6.185A.

Feyereisen G.W., T.C. Strickland, D.D. Bosch, and D.G. Sullivan. 2007. Evaluation of SWAT manual calibration and input parameter sensitivity in the Little River Watershed. Transactions of the American Society of Agricultural and Biological Engineers 50(3):843-855.

Fuentes, J.P., M. Flury, and D.F. Bezdicek. 2004. Hydraulic properties in a silt loam soil under natural prairie, conventional till, and no-till. Soil Science Society America Journal 68:1679-1688.

Gantzer, C.J., and S.H. Anderson. 2002. Computed tomographic measurement of macroporosity in chisel- 
disk and no-tillage seedbeds. Soil Tillage Research 64:101-111

Ghidey, F., and E.E. Alberts. 1999. Temporal and spatial patterns of nitrate in a claypan soils. Journal of Environment Quality 28:584-594.

Ippisch, O., H.-J. Vogel, and P. Bastian. 2006. Validity limits for the van Genuchten-Mualem model and implications for parameter estimation and numerical simulation. Advances in Water Resources 29(12):1780-1789.

Jagadamma, S., R. Lal, and B.K. Rimal. 2009. Effects of topsoil depth and soil amendments on corn yield and properties of two Alfisols in central Ohio. Journal of Soil and Water Conservation 64(1):70-80, doi:10.2489/jswc.64.1.70.

Jiang, P., S.H. Anderson, N.R. Kitchen, E.J. Sadler, and K.A. Sudduth. 2007a. Landscape and conservation management effects on hydraulic properties of a claypan soil toposequence. Soil Science Society America Journal 71:803-811.

Jiang, P., S.H. Anderson, N.R. Kitchen, K.A. Sudduth, and E.J. Sadler. 2007b. Estimating plant-available water capacity for claypan landscapes using apparent electrical conductivity. Soil Science Society America Journal 71:1902-1908.

Jury, W.A., W.R. Gardner, and W.H. Gardner. 1991. Soil physics. New York: John Wiley \& Sons.

Kitchen, N.R., K.A. Sudduth, D.B. Myers, R.E. Massey, E.J Sadler, R.N. Lerch, J.W. Hummel, and H.L. Palm. 2005. Development of a conservation-oriented precision agriculture system:Assessment and plan implementation. Journal of Soil and Water Conservation 60(6):421-430.

Klute, A. 1986. Water retention: Laboratory methods. In Methods of Soil Analysis. Part 1.2nd ed., ed.A. Klute, 635662. Agron. Monogr. 9. Madison, WI: American Society of Agronomy and Soil Science Society of America.

Klute, A., and C. Dirksen. 1986. Hydraulic conductivity and diffusivity: Laboratory methods. In Methods of Soil Analysis. Part 1. 2nd ed., ed. A. Klute, 687-734. Agron. Monogr. 9. Madison, WI: American Society of Agronomy and Soil Science Society of America.

Kucera, C.L., R. Dahlman, and M. Koelling. 1967. Total net productivity and turnover on energy basis for tallgrass prairie. Ecology 48:536-541.

Lal, R., and W.C. Moldenhauer. 1987. Effects of soil erosion on crop productivity. Critical Reviews in Plant Sciences 5(4):303-367.

Larson, W.E., FJ. Pierce, and R.H. Dowdy. 1983. The threat of soil erosion to long-term crop production. Science 219:458-465.

Lerch, R.N., N.R. Kitchen, R.J. Kremer, W.W. Donald, E.E. Alberts, E.J. Sadler, K.A. Sudduth, D.B. Myers, and F. Ghidey. 2005. Development of a conservation-oriented precision agriculture system: Water and soil quality assessment. Journal of Soil and Water Conservation 60(6):411-420.

Lu, S., R. Tusheng, G. Yuanshi, and R. Horton. 2008. Evaluation of three models that describe soil water retention curves from saturation to oven dryness. Soil Science Society America Journal 72(6):1542-1546.

Meek, B.D., E.R. Rachel, L.M. Carter,W.R. DeTar, and A.L. Urie. 1992. Infiltration rate of a sandy loam soil: Effect of traffic, tillage, and plant roots. Soil Science Society America Journal 56:908-913.

Mudgal, A., C. Baffaut, S.H. Anderson, E.J. Sadler, and A.L. Thompson. 2008. APEX model assessment of variable landscapes on runoff and dissolve herbicides. Paper no. 084498, St. Joseph, MI:American Society of Agricultural and Biological Engineers.

Or, D., FJ. Leij,V. Snyder, and T.A. Ghezzehei. 2000. Stochastic model of post tillage soil pore space evolution. Water Resource Research 36:1641-1652.

Pierce, FJ., W.E. Larson, R.H. Dowdy, and W.A.P. Graham. 1983. Productivity of soils: Assessing long term changes due to erosion. Journal Soil Water Conservation 38(1):39-44.

Rachman, A., S.H. Anderson, C.J. Gantzer, and E.E. Alberts. 2004. Soil hydraulic properties influenced by stiffstemmed grass hedge systems. Soil Science Society America Journal 68(4):1386-1393.

Rousseva, S.S., L.R. Ahuja, and G.C. Heathman. 1988 Use of a surface gamma-neutron gauge for in-situ measurements of changes in bulk density of the tilled zone. Soil Tillage Research 12:235-251.

SAS (Statistical Analysis Systems) Institute. 1999. SAS user's guide. Statistics. Cary, NC: Statistical Analysis Systems Institute.

Scott, H.D., and L.S. Wood. 1989. Impact of crop production on the physical status of a Typic Albaqualf. Soil Science Society America Journal 53(6):1819-1825.

Scrivner, C.L., P.G. Koeing, and B.L. Conkling. 1985. The effects of soil erosion upon soil productivity in Missouri farm fields. University of Missouri, Columbia, extension circular 950 .

Seobi, T., S.H. Anderson, R.P. Udawatta, and C.J. Gantzer. 2005. Influence of grass and agroforestry buffer strips on soil hydraulic properties for an Albaqualf. Soil Science Society America Journal 69(3):893-901.

Skaggs, R.W., D.M. Amatya, G.M. Chescheir, C.D. Blanton, and J.W. Gilliam. 2006. Effect of drainage and management practices on hydrology of Pine Plantation. Hydrology and Management of Forested Wetlands Proceedings of the International Conference April 8$12,2006$.

Spruill, C.A., S.R. Workman, and J.L. Taraba. 2000 Simulation of daily and monthly stream discharge from small watersheds using the SWAT model. Transactions of the American Society of Agricultural Engineers 43(6):1431-1439.

Udawatta, R.P., S.H.Anderson, C.J. Gantzer, and H.E. Garrett. 2008. Influence of prairie restoration on CT-measured soil pore characteristics. Journal of Environmental Quality 37(1):219-228.

Udawatta, R.P., and G.S. Henderson. 2003. Root distribution relationships to soil properties in Missouri Oak Stands: A productivity index approach. Soil Science Society America Journal 67:1869-1878.

USDA NRCS (Natural Resources Conservation Service). 2008 Soil Survey Geographic (SSURGO) Database. Survey area version 9 for Boone and Callaway County, Missouri.

van Dijck, S.J.E., W. Th, and J. van Asch. 2002. Compaction of loamy soils due to tractor traffic in vineyards and orchards and its effect on infiltration in southern France. Soil Tillage Research 63:141-153.

van Genuchten, M., and M. Th. 1980. A closed-form equation for predicting the hydraulic conductivity of unsaturated soils. Soil Science Society America Journal 44(5):892-898

van Genuchten, M. Th., F.J. Leij, and S.R. Yates. 1991. The RETC Code for Quantifying the Hydraulic Functions of Unsaturated Soils. US Environmental Protection Agency, EPA/600/2-91/065, Washington DC.

van Rompaey, A.J.J., G. Govers, E. van Hecke, and K. Jacobs. 2001. The impacts of land use policy on the soil erosion risk: A case study in central Belgium. Agriculture, Ecosystems and Environment 83(1-2):83-94.

White, K.L., and I. Chaubey. 2007. Sensitivity analysis, calibration, and validations for a multisite and multivariable SWAT model. Journal of the American Water Resource Association 41(5):1077-1089. 